DOI https://doi.org/10.30525/978-9934-588-91-4-22

\title{
ГОЛОВНІ УБОРИ ТА АКСЕСУАРИ ВОЛИНЯН СЕРЕДИНИ ХVІ СТОЛІТТЯ
}

\author{
Тарасюк М. Ю. \\ аспірантка кафедри історії \\ Національного технічного університету України \\ «Київський політехнічний інститут імені Ігоря Сікорського» \\ м. Київ, Україна
}

Дослідження гардеробу наших пращурів не лише сприяє розумінню модних тенденцій у тому чи іншому регіоні у певний відрізок часу, як-от за часів Великого князівства Литовського (далі - ВКЛ), але й містить у собі відповідь на питання яким було матеріальне становище представника певного соціального стану та свідчить про прояв особистісних вподобань середньовічної людини через використання тих чи інших елементів власного гардеробу. За побутуванням у суспільстві певних головних уборів та аксесуарів маємо змогу простежити довготривалі місцеві традиції у конкретному регіоні. У даному випадку, на Волині. Актуальність роботи обумовлена недостатнім ступенем дослідження на сьогоднішній день гардеробу волинян нешляхетного походження - міщан та селян - що, як підкреслює В. Безпалько $[4$, c. 58] щодо останніх, часто здаються нам бідними, а їхнє вбрання та аксесуари - одноманітними та дешевими.

Гардероб волинян (у тому числі й головні убори та аксесуари) розглядається у доробках таких науковців як В. Безпалько $[2 ; 3 ; 4]$, Г. Стельмащук [6], нариси котрих, хоч і стосуються здебільшого другої половини або кінця XVI ст., містять декотру інформацію про сформовані види одягу та головних уборів у більш ранні часи. Наше дослідження не передбачає етнологічної розвідки, а $\epsilon$ спробою 3'ясування різноманіття головних уборів та аксесуарів, доступних волинським міщанам та селянам та наявності особистісних вподобань у формуванні власного образу.

Варто зазначити, що головні убори як жіночого, так і чоловічого гардеробу, могли шити як з місцевих тканин та хутра, забезпечуючи їх доступність простому населенню, так і з імпортних матеріалів, що підвищувало вартість виробу. Теж саме стосується і аксесуарів: ременів, сумок для грошей, намиста, перснів тощо.

Серед чоловічих уборів найбільш розповсюдженими та можливими для реконструкції були шапки. Матеріал для виготовлення був різноманітним: шили з куниці, соболів, шкіри коня, обшивали лисячим чи баранячим хутром. Про шапку, пошиту з куниці, згадано в заяві про 
обкрадання Сивицкого в помісті Рудці у 1561 році [5, с. 172]. Такі шапки 3 куниці, на нашу думку, були доступні для простих селян $\mathrm{i}$ міщан, адже ця тварина була поширена по всій Волині, а тому іiі хутром навіть сплачували податки. Натуральний колір такого убору був коричневим. Оскільки ще у 1501 р. лучани сплачували ординщину у розмірі «сорокь соболей» [1, с. 343] (тварина у той період часу ще була представлена на теренах України), хутро могло використовуватися як для пошиття верхнього одягу, так і для головного убору, хоча її вартість, припускаємо, була значно вищою, оскільки кількість соболів могла бути незначною. Заможні чоловіки мали у своєму гардеробі шапки-шлики 3 гострим чи опуклим наголовком 3 дорогого хутра чи тканини, про що зазначає дослідниця Г. Стельмащук [6, с. 901]. Про те, що шапки носили усі, свідчить, зокрема, скарга 1561 р. до Луцького замкового уряду, де у семи осіб обібрали по шапці, як свідчили Василь Семашко і Гаврило Бокей [5, с. 182-183]. У декотрих з постраждалих чоловіків був головний убір, обшитий куницею. Одну з шапок було оцінено у сім грошей, іншу шапку з хусткою - у десять, а третій убір та пояс - у вісім грошей, що мусило б свідчити про залежність цієї вартості від якості та матеріалу виготовлення. У 1565 р. під час огляду возу острозького купця Івана Плескача було описано шапки чорні і темно-червоні 3 ковпаками [7, с. 112].

Дещо пізніша згадка міститься у судовій справі за 1580 рік, яка засвідчує існування чоловічих баранячих шапок: «...шапку чоръную, за пять грошеи купленую» [8, с. 328]. Припускаємо, що такий різновид головного убору існував і за доби ВКЛ.

Іншим різновидом шапки була «кучма». $\mathcal{C}$ згадка про виготовлену 3 коня кучму, що належала Свхиму Дуброві у січні 1561 року, а, отже, цей убір був достатньо теплим для зими [5, с. 201]. Свхим був радником у Дубні i, хоч й не згадується як пан, але з опису украдених у нього речей зрозуміло, що його матеріальне становище було добрим.

Жіночі убори широкого вживання були представлені хустками, чепцями, а інколи - й шапками. Цікавою, на нашу думку, є згадка про два чепці [5, с. 258] - основний жіночий убір, у який зашнуровували волосся заміжні. Згадка про хустки міститься у багатьох заявах про крадіжку. Наприклад, у луцького міщанина Василя Лукашевича у 1561 році [5, с. 155]. Хоча зустрічаються випадки крадіжки хустки у чоловіка, як то сталося 3 любецьким урядником Криштофом Воине [5, с. 172]. Однак, ймовірніше всього, у цьому випадку йдеться про місткість для грошей. У святкові дні жінки могли ходити вулицями 3 непокритою головою [6, с. 904].

На нашу думку, аксесуари використовували для відзначення свого статусу, з естетичних уподобань та $з$ практичних міркувань. Саме тому носіння тих чи інших аксесуарів було притаманним не лише вищим верствам суспільства, але й міщанам та селянам - для підкреслення 
свого матеріального благополуччя. Вони були представлені поясами, гудзиками, перстнями, намистом, різноманітними видами сумок. Лікар Влох, наприклад, у заяві про крадіжку згадував два золоті перстні 3 дорогоцінними каміннями: «Один диамєн и два рубины, которые мне коштоваль сорокь талєреи», а також перстні з коштовним камінням за 30 талерів [8, с. 137], що свідчить про прибутковість його професійної діяльності. У місті Рівному серед поховань було знайдено перстні 3 кольорових металів, медальйони, намисто і сережки [9, с. 102]. Знайдені приклади намиста, виготовлені 3 кольорового скла [9, с. 153], говорять про доступність такої прикраси небагатим верствам населення, але, у той же час, свідчать про прагнення тогочасної людини виглядати привабливо.

Надзвичайно популярними серед чоловіків були пояси для носіння зброї чи грошей. Маємо згадку, датовану 1560 р., про вкрадений у Васка Кучевича пояс із ножами тощо [5, с. 149, 322]. У іншій справі про крадіжку описуються пояс із вачком (для носіння грошей) та пояс із калиткою [5, с. 183], ймовірніше всього, з металевою застібкою, у Криштофа Воине.

Існувало різноманіття чоловічих сумок для грошей. Найчастіше у джерелах згадується «мошонка», хоча, як зазначає В. Безпалько, побутує і скорочене найменування «мошна» [2, с. 567]. Так, у підданого Раиского у 1561 р. украли «мошонку с полчвартма гршми», а у його колеги Сивицкого - більший оксамитовий мішок 3 копою грошей [5, с. 172]. Зустрічається назва «сумка 3 пензями», що іï украли у Заборолі [5, с. 156] чи пояс з вачком, про який зазначалося вище.

Отже, головні убори та аксесуари міщан та селян Волині у середині XVI ст. були різноманітними: шапки 3 куниці, соболів, шкіри коня, баранячої вовни чи обшиті лисом, шапки-шлики, чіпці, жіночі хустки тощо. Серед аксесуарів побутували намиста, перстні, пояси для носіння грошей та зброї, а також різні види сумок - сумки, вачки, мошни, мішки тощо. 3'ясовано, що вироби могли бути різноманітних кольорів, оздоблення, матеріалу виготовлення i, як результат, різної вартості, що давало можливість міщанам та селянам сформувати гардероб за власним вподобанням у доступній їм ціновій категорії. Більше того, наявність різноманіття аксесуарів та головних уборів у гардеробі однієї й тієї ж людини свідчило про ії̈ аж ніяк не злиденне майнове становище у більшості випадків, а також і мало підкреслити сам факт існування достатку.

\section{Література:}

1. Акты, относящиеся к истории Западной России, собранные и изданные Археографической комиссией. Том I (1340-1506). С-Пб: Тип. II Отделения Собственной Е. И. В. Канцелярии, 1846. 428 с. 
2. Безпалько В. Аксесуари одягу для носіння грошей у населення Волині в останній чверті XVI ст. (за актовими джерелами). Спеціальні історичні дисципліни: питання теорї та методики. Збірка наукових пращь. Київ: Інститут історії України, 2013. С. 566-577.

3. Безпалько В. Матеріали виготовлення верхнього одягу селян українських селян другої половини XVI-XVII ст. (за актовими джерелами Волині). Ukraina Lithuanica: студіï з історії Великого князівства Литовського. Київ - Кам'янець-Подільський, 2017. T. IV. С. 232-247.

4. Безпалько В. Селянський святковий одяг на Волині останньої третини XVI ст. за актовим матеріалом. Украӥна і Велике князівство Литовське в XIV-XVIII ст.: політичні, економічні, міжнаціональні та соиіокультурні відносини у загальноєвропейському вимірі: тези доп. III Міжнар. наук. конф. (16-19 жовтня 2013). Київ, 2013. С. 58-59.

5. Луцька замкова книга 1560-1561рp./ Підгот. до вид. В. Мойсієнко, В. Поліщук. Луцьк, 2013. 733 с.

6. Стельмащук Г. Вбрання на Волині у XIV - XVIII століттях і побутування окремих його компонентів у селян до середини XX ст. Народознавчі зошити. 2017. № 4 (136). С. 896-913.

7. Торгівля на Україні, XIV - середина XVII століття: Волинь і Наддніпрянщина / Упорядн. В. Кравченко, Н. Яковенко. Київ, 1990. 408 с.

8. Українське повсякдення ранньомодерної доби: збірник документів. Вип. 1: Волинь XVI ст. НДІ укр-ва МОН України, ЦЦІА України, ГО «Центр досліджень та відродження Волині». Київ, 2014. 776 с.

9. Чекурков В. Дисертація. Міста на території Луцького повіту Волинського воєводства другої половини XIV - першої половини XVII століть. Рівне, 2018. 375 с. URL: https://shron1.chtyvo.org.ua/Chekurkov Vasyl/Mista_na_terytorii_Lutskoho_povitu_Volynskoho_voievodstva_druho i_polovyny_XIV__pershoi_polovyny_XVII.pdf? (дата звернення 10.09.2020) 